\title{
PENGOLAHAN KAKAO BUBUK DARI BIJI KAKAO FERMENTASI DAN TANPA FERMENTASI SEBAGAI SEDIAAN BAHAN PANGAN FUNGSIONAL
}

\author{
Processing of Cocoa Powder From Fermented and Unfermented Cocoa Beans \\ as a Supply of Functional Food
}

\author{
Rosniati dan Kalsum \\ Balai Besar Industri Hasil Perkebunan \\ JI. Prof. Dr. Abdurahman Basalamah No. 28, Makassar 90231 \\ e-mail : rosniatik@yahoo.com
}

\begin{abstract}
Study of cocoa powder processing from fermented and unfermented cocoa beans as functional food ingredients has been carried out. The aim of this study was to know the functional compounds (polyphenol and amino acid) content from fermented cocoa beans, unfermented cocoa beans and cocoa powder processed from (fermented-roasted cocoa beans) and from (unfermented-unroasted cocoa beans). The study consisted of 4 treatments, i.e : A (fermented cocoa beans), B (unfermented cocoa beans), $C$ (cocoa powder processed from fermented-roasted cocoa beans) and $D$ (cocoa powder from unfermented-unroasted cocoa beans). The results show that unfermented and fermented cocoa beans polyphenol content were $15.09 \%$ and $13.95 \%$, respectively. Polyphenol content of cocoa powder from (unfermented-unroasted cocoa beans) and from (fermented - roasted) were $14.03 \%$ and $11.60 \%$, respectively. Unfermented and fermented cocoa beans amino acid content were $8.55 \%$ and $9.26 \%$, respectively. Amino acid content of cocoa powder from (unfermented-unroasted cocoa beans) and from (fermented-roasted cocoa beans) were $16.81 \%$ and $21.99 \%$, respectively. The content of polyphenols and amino acids in cocoa powder greatly contributes to personal health, that usefull as functional food ingredients.
\end{abstract}

Keywords: fermented and unfermented cocoa beans, cocoa powder, polyphenol, and amino acid.

\begin{abstract}
Abstrak Penelitian pengolahan kakao bubuk dari biji kakao fermentasi dan tanpa fermentasi sebagai sediaan bahan pangan fungsional telah dilakukan. Tujuan penelitian ini adalah untuk mengetahui kandungan senyawa fungsional (polifenol dan asam amino) dari biji kakao fermentasi, tanpa fermentasi, kakao bubuk yang diolah dari biji kakao (fermentasi - sangrai) dan dari biji kakao (tanpa fermentasi - tanpa sangrai). Penelitian ini terdiri dari 4 perlakuan yaitu: A (biji kakao fermentasi), B (biji kakao tanpa fermentasi), $\quad$ C (Kakao bubuk dari biji tanpa fermentasi - tanpa sangrai), dan D (Kakao bubuk dari biji fermentasi - sangrai). Hasil penelitian menunjukkan bahwa kandungan polifenol dari biji tanpa fermentasi dan fermentasi masing-masing 15,09 \% dan 13,95 \%. Sedangkan kakao bubuk dari (biji kakao tanpa fermentasi - tanpa sangrai) dan dari (biji kakao fermentasi - sangrai) masing-masing 14,03\% dan 11,60 $\%$. Perlakuan biji kakao tanpa fermentasi dan fermentasi mempunyai kandungan asam amino masingmasing 8,55 \% dan 9,26 \%. Sedangkan kakao bubuk dari (biji kakao tanpa fermentasi - tanpa sangrai) dan dari (biji kakao fermentasi - sangrai) masing-masing 16,81 \% dan 21,99\%. Kandungan senyawa polifenol dan asam amino pada kakao bubuk sangat berkontribusi untuk menyehatkan tubuh, sehingga dapat digunakan sebagai sediaan bahan pangan fungsional.
\end{abstract}

Kata Kunci: Biji kakao fermentasi dan tanpa fermentasi, kakao bubuk, polifenol, dan asam amino.

\section{PENDAHULUAN}

Indonesia merupakan salah satu negara produsen kakao terbesar ketiga Dunia setelah Pantai Gading dan Ghana dengan produksi sebesar $13 \%$ dari produksi kakao Dunia, sedangkan Pantai Gading dan Ghana masing-masing adalah 39\% dan 19\% (ICCO, 2012). Produksi kakao Indonesia sangat diperhitungkan dalam perdagangan kakao Dunia dikarenakan biji kakao asal Indonesia memiliki kandungan senyawa polifenol yang relatif lebih tinggi dibandingkan biji kakao yang berasal dari Pantai Gading, Ghana dan Malaysia (Othman et al., 2010). Hal tersebut dapat meningkatkan daya saing kakao Indonesia di pasar internasional menjadi lebih baik. 
Sejumlah hasil riset menunjukkan bahwa proses fermentasi, pengeringan, dan proses termal lainnya pada pengolahan kakao dapat menyebabkan berkurangnya kandungan polifenol dan aktivitas antioksidan pada biji kakao dan produk olahannya (De-Brito et al, 2000, dan Albertini et al, 2015). Hal ini menyebabkan berkurangnya jumlah antioksidan hasil produk olahan kakao. Nazaruddin et al., 2006 melaporkan kandungan senyawa polifenol dalam biji kakao yang tidak difermentasi, lebih banyak dibandingkan dengan biji kakao fermentasi, karena pada proses fermentasi senyawa polifenol terdegradasi melalui proses oksidasi, polimerisasi, dan pengikatan oleh protein. Oleh karena itu, pengembangan produk pangan fungsional dan makanan kesehatan (health foods) dari kakao, hendaknya dilakukan dengan mereduksi tahapan proses atau meminimalkan efek proses yang secara signifikan berpotensi menurunkan kandungan polifenol pada biji dan produk olahan kakao. Tahapantahapan proses itu termasuk fermentasi, penyangraian, dan alkalisasi biji kakao (Yunus et al., 2013).

Kandungan senyawa polifenol yang terdapat pada biji kakao segar dan belum dilakukan proses fermentasi adalah 1218\% (Othman et al., 2007; Cooper et al., 2007; Afoakwa et al., 2012; Ackar et al., 2013). Kandungan senyawa polifenol pada biji kakao meliputi katekin $33-42 \%$, leukosianidin 23 - $25 \%$, dan antosianin $5 \%$. Sedangkan pada kakao bubuk bebas lemak mengandung 5-18 \% senyawa polifenol (Kusuma et al., 2013). Senyawa polifenol merupakan senyawa kimia yang mempunyai sifat antioksidan, yang sangat penting dalam peranannya menyehatkan tubuh manusia (Crozier et al., 2011).

Kandungan senyawa polifenol pada kakao maupun produk turunannya seperti kakao bubuk sangat berkontribusi untuk menyehatkan tubuh, karena mempunyai peran sebagai antioksidan, anti kanker, anti diabetes, anti hipertensi, anti inflamasi, menghilangkan stres, mencegah karies gigi, kemampuan kognitif, meningkatkan resistensi terhadap hemolisis, menyehatkan jantung dan sebagai aprodisiak (Kelishadi, 2005; Afoakwa, 2008; Nestle Research Centers, 2010; Watson et al., 2012; Ackar et al., 2013; Latif, 2013). Kakao bubuk merupakan salah satu produk olahan dari biji kakao fermentasi atau tanpa fermentasi yang diperoleh melalui proses penyangraian, alkalisasi, pengeluaran kulit ari, pemastaan, pemisahan lemak dan bungkil. Bungkil kakao yang telah dihaluskan dan diayak dengan ayakan ukuran 200 mesh disebut kakao bubuk. Selain kandungan senyawa polifenol, senyawa asam amino dalam kakao juga dipengaruhi oleh proses fermentasi, pengeringan dan proses thermal lainnya.

Tujuan penelitian ini adalah untuk mengetahui kandungan senyawa fungsional dari biji kakao fermentasi, tanpa fermentasi, kakao bubuk yang diolah dari biji kakao (fermentasi - sangrai) serta dari biji kakao (tanpa fermentasi - tanpa sangrai)

\section{METODOLOGI}

\section{Bahan dan Alat}

Bahan baku yang digunakan pada penelitian ini adalah buah kakao dari Kabupaten Bantaeng. Alat proses yang digunakan adalah alat pemecah buah, alat pemeras lendir kakao (depulper), kotak fermentasi, para-para penjemuran, alat penyangrai (Roaster), alat pengepress lemak kakao, alat pembubuk, dan alat pengayak.

\section{Metode Penelitian}

Penelitian ini terdiri atas 2 (dua) tahap. Tahap pertama adalah persiapan biji kakao fermentasi dan tanpa fermentasi dan tahap ke dua adalah persiapan kakao bubuk sebagai sediaan bahan pangan fungsional.

\section{Penelitian Tahap Pertama}

\section{Penyiapan biji kakao fermentasi dan tanpa fermentasi}

Penyiapan biji kakao fermentasi dari biji basah menggunakan prosedur standar (Mulato et al., 2005), kecuali biji kakao yang digunakan adalah biji kakao tanpa fermentasi. Pengeringan biji kakao dilakukan dengan penjemuran terlindung untuk menjaga biji kakao yang sedang dikeringkan 
tidak terkena matahari langsung, khususnya pada saat terik, sampai diperoleh kadar air biji 6-7 \%.

\section{Penyiapan kakao bubuk sebagai sediaan bahan pangan fungsional}

Biji kakao kering hasil fermentasi disangrai terlebih dahulu pada suhu $100^{\circ}$ C selama 40 menit, sedangkan biji kakao kering tanpa fermentasi tidak disangrai. Hal ini dilakukan untuk meminimalkan terjadinya penurunan kandungan polifenol dalam biji kakao. Selanjutnya ke dua jenis biji kakao dilakukan pengeluaran kulit ari menggunakan desheller kemudian masing-masing digiling dengan menggunakan universal counching machine, sehingga diperoleh pasta kakao. Selanjutnya pasta kakao dipress menggunakan alat press lemak kakao type CBP - 30 dengan pompa piston tekanan tinggi (high pressure piston pump) $60 \mathrm{~atm}$, suhu $55^{\circ} \mathrm{C}$ untuk memisahkan lemak kakao dan bungkil kakao. Bungkil kakao yang diperoleh digiling dengan menggunakan mesin pembubuk, kemudian diayak menggunakan ayakan ukuran 200 mesh, sehingga dihasilkan kakao bubuk fermentasi dan tanpa fermentasi. Kakao bubuk yang dihasilkan dianalisis kadar air dan kadar lemaknya. Kadar air kakao bubuk dari biji fermentasi-sangrai dan kakao bubuk dari biji tanpa fermentasi - tanpa sangrai masingmasing 5,0\%, sedangkan kadar lemak kakao bubuk dari biji fermentasi-sangrai rata-rata $18,37 \%$ dan kadar lemak kakao bubuk dari biji tanpa fermentasi - tanpa sangrai ratarata $12,03 \%$.

Perlakuan penelitian ada 4 yaitu :

A : Biji kakao Tanpa Fermentasi

B : Biji Kakao Fermentasi

C :Kakao bubuk dari Biji Kakao (Tanpa Fermentasi - Tanpa Sangrai)

D: Kakao bubuk dari Biji Kakao (Fermentasi - Sangrai)

\section{Metode Analisis}

Analisis biji kakao dan kakao bubuk dilakukan terhadap total polifenol dengan metode HPLC dan asam amino dengan metode asam amino analyser.
Analisis data

Data hasil uji laboratorium diolah secara deskripsi.

\section{HASIL DAN PEMBAHASAN}

\section{Polifenol Biji Kakao dan Kakao bubuk}

Hasil analisis total polifenol biji kakao tanpa fermentasi, fermentasi, kakao bubuk dari biji kakao (tanpa fermentasi tanpa sangrai) dan kakao bubuk dari biji kakao (fermentasi - sangrai) dapat dilihat pada Gambar 1. Pada Gambar 1, terlihat bahwa kadar total polifenol biji kakao tanpa fermentasi yaitu 15,09 \% (A) dan biji kakao fermentasi 13,95 \% (B), sedangkan total polifenol kakao bubuk dari biji kakao (tanpa fermentasi - tanpa sangrai) $14,03 \%$ (C) dan kakao bubuk dari biji kakao (fermentasi sangrai) $11,60 \%$ (D).

Rendahnya kadar total polifenol pada biji kakao fermentasi disebabkan karena selama fermentasi terjadi penguraian senyawa polifenol menjadi calon citarasa dan membentuk warna coklat mengakibatkan senyawa polifenol terdifusi keluar dari keeping biji. Menurut Misnawi et al., (2004) dan Redovnikovic et al., (2009) bahwa senyawa polifenol yang terkandung dalam biji kakao sangat berkontribusi dalam memberikan rasa sepat dan pahit pada kakao. Adanya pengurangan rasa pahit dan sepat pada proses fermentasi, disebabkan karena terjadinya penurunan kandungan polifenol pada biji kakao. Hal ini merupakan peristiwa yang harus terjadi untuk membentuk citarasa dan aroma cokelat yang baik (Wollgast dan Anklam, 2000; Misnawi, 2003). Namun disisi lain polifenol sangat dibutuhkan untuk kesehatan. 


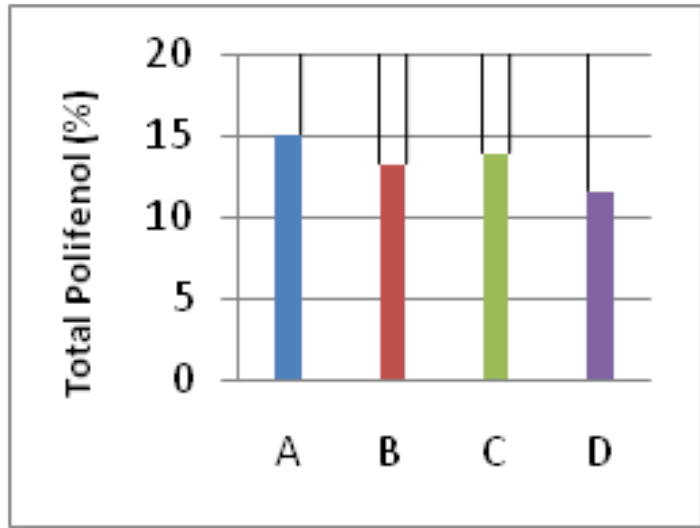

Gambar 1. Histogram kadar total polifenol biji kakao fermentasi, tanpa fermentasi, kakao bubuk dari biji kakao (tanpa fermentasi - tanpa sangrai) dan kakao bubuk dari biji kakao (fermentasi - sangrai).

Ket :

A : Biji kakao tanpa fermentasi

B : Biji kakao fermentasi

C : Kakao bubuk dari biji kakao (tanpa fermentasi-tanpa sangrai)

D : Kakao bubuk dari biji kakao (fermentasisangrai)

Menurut De-Brito, et al., (2000), Misnawi dan Jinap (2003) serta Afoakwa et al., (2012), penurunan kandungan senyawa polifenol selama fermentasi disebabkan adanya peristiwa oksidasi polifenol oleh enzim polifenol oksidase, difusi polifenol dari kotiledon menuju lapisan kulit, terjadinya polimerisasi senyawa polifenol terutama epicatechin dan proanthocyanidin membentuk senyawa tannin, dan terjadinya pembentukan kompleks dengan protein dan polisakarida. Selanjutnya DiMattia et al., (2013) dan Afoakwa et al., (2013) menyatakan terjadinya reaksi polimerisasi polifenol dan pembentukan kompleks dengan senyawa lain, menambah kelarutan polifenol yang hilang terbawa cairan pulpa.

Pada Gambar 1, juga terlihat bahwa kadar total polifenol kakao bubuk yang diolah dari biji kakao (fermentasi - sangrai) lebih rendah dibanding dengan yang diolah dari biji kakao (tanpa fermentasi tanpa sangrai). Hal ini disebabkan karena pada pengolahan kakao bubuk dari biji fermentasi melalui proses penyangraian, sehingga polifenol teroksidasi menyebabkan terjadinya pengurangan senyawa polifenol dari biji kakao. Sedangkan kakao bubuk dari biji tanpa fermentasi tidak dilakukan proses penyangraian. Pengolahan biji kakao (tanpa fermentasi - tanpa sangrai) sampai menjadi kakao bubuk, penuruanan kandungan polifenol sebesar $1,06 \%$, sedangkan pengolahan biji kakao (fermentasi sangrai) sampai menjadi kakao bubuk terjadi penurunan polifenol sebesar 2,35\%. Tingginya persentase penurunan polifenol pada pengolahan kakao bubuk dari biji kakao (fermentasi - sangrai) disebabkan karena proses fermentasi dan proses penyangraian biji kakao.

Janeiro dan Brett (2004) menyatakan bahwa senyawa polifenol terutama catechin akan rusak karena proses oksidasi. Adanya proses oksidasi yang intensif selama penyangraian menyebabkan terjadinya pengurangan senyawa polifenol dari biji kakao. Selama proses penyangraian, biji kakao akan mengalami perubahan sifat fisika dan kimia, dimana senyawa pembawa citarasa dan aroma khas cokelat seperti pirazin, karbonil, ester dan sebagainya meningkat secara nyata selama proses penyangraian (Noor-Soffalina et al., 2009). Oleh karena itu, untuk meminimalisir kehilangan senyawa polifenol pada saat penyangraian, maka pada penelitian ini dilakukan penyangraian biji kakao pada suhu rendah $\left(100^{\circ} \mathrm{C}\right)$ selama 40 menit lebih rendah dari pada penyangraian biji kakao yang pada umumnya dilakukan untuk pembuatan kakao bubuk konvensional, sehingga proses oksidasi senyawa polifenol tidak banyak mengalami perubahan.

Penyangraian biji kakao umumnya dilakukan pada suhu $110-220^{\circ} \mathrm{C}$ selama 30 - 35 menit sesuai tipe biji. Biji kakao Ghana memerlukan perlakuan suhu yang relatif tinggi, yaitu antara $148-184$ - C, sedangkan biji kakao Caracas dan Maracaibos memerlukan suhu sangrai yang lebih rendah, yaitu $131-146{ }^{\circ} \mathrm{C}$ (Meursing, 1983). Menurut Minifie, 1982, penyangraian biji kakao dilakukan pada suhu $140^{\circ} \mathrm{C}$ selama 35-40 menit untuk pengolahan kakao bubuk. Suhu penyangraian diatas 100 
${ }^{\circ} \mathrm{C}$ menyebabkan kehilangan flavanol 10

$\%$. Semakin tinggi suhu dan dan semakin lama waktu penyangraian menyebabkan kehilangan polifenol yang lebih besar (Cruz et al., 2013).

\section{Asam Amino Biji Kakao dan Kakao bubuk}

Hasil analisis asam amino biji kakao tanpa fermentasi, biji kakao fermentasi, kakao bubuk dari biji kakao (tanpa fermentasi
- tanpa sangrai), dan kakao bubuk dari biji kakao (fermentasi - sangrai) dapat dilihat pada Tabel 1. Pada Tabel 1, terlihat bahwa kadar total asam amino biji kakao tanpa fermentasi yaitu 8,55 \% (A) dan biji kakao fermentasi 9,26\% (B), sedangkan total asam amino kakao bubuk dari biji kakao (tanpa fermentasi - tanpa sangrai) 16,81\% (C) dan kakao bubuk dari biji kakao (fermentasi sangrai) $21,99 \%$ (D).

Tabel 1. Kadar total asam amino biji kakao fermentasi, tanpa fermentasi, kakao bubuk dari biji kakao (tanpa fermentasi - tanpa sangrai) dan kakao bubuk dari biji kakao

(fermentasi - sangrai)

\begin{tabular}{ccccc}
\hline Asam Amino & $\begin{array}{c}\text { Biji Kakao } \\
\text { Tanpa } \\
\text { Fermentasi } \\
\mathbf{( \% )}\end{array}$ & $\begin{array}{c}\text { Biji Kakao } \\
\text { Fermentasi } \\
\mathbf{( \% )}\end{array}$ & $\begin{array}{c}\text { Kakao bubuk } \\
\text { dari Biji Tanpa } \\
\text { Fermentasi-Tanpa } \\
\text { Sangrai } \\
\mathbf{( \% )}\end{array}$ & $\begin{array}{c}\text { Kakao bubuk } \\
\text { dari Biji } \\
\text { Fermentasi - } \\
\text { Sangrai (\%) }\end{array}$ \\
\hline Metionin & 0.1 & 0.04 & 0.21 & 0.26 \\
\hline Fenilalanin & 0.52 & 0.61 & 1.07 & 1.36 \\
\hline Leusin & 0.64 & 0.71 & 1.25 & 1.63 \\
\hline Treonin & 0.46 & 0.48 & 0.9 & 1.05 \\
\hline Lisin & 0.46 & 0.41 & 0.96 & 1.5 \\
\hline Arginin & 0.71 & 0.81 & 1.44 & 1.89 \\
\hline Iso Leusin & 0.41 & 0.47 & 0.74 & 0.47 \\
\hline Histidin & 0.22 & 0.19 & 0.36 & 1.47 \\
\hline Valin & 0.58 & 0.65 & 1.07 & 2.54 \\
\hline Asam Aspartat & 1.03 & 1.18 & 2.03 & 4.29 \\
\hline Asam Glutamat & 1.67 & 1.83 & 3.28 & 1.18 \\
\hline Serin & 0.46 & 0.54 & 1.01 & 1.08 \\
\hline Glisin & 0.43 & 0.35 & 0.75 & 1.09 \\
\hline Alanin & 0.43 & 0.49 & 0.86 & 1.16 \\
\hline Tirosin & 0.43 & 0.5 & 0.88 & $\mathbf{2 1 , 9 9}$ \\
\hline Total & $\mathbf{8 . 5 5}$ & $\mathbf{9 . 2 6}$ & $\mathbf{1 6 , 8 1}$ &
\end{tabular}

Dari Tabel 1, terlihat bahwa total asam amino biji kakao fermentasi lebih tinggi dari pada biji kakao tanpa fermentasi, demikian pula kakao bubuk dari biji kakao (fermentasi sangrai) lebih tinggi dari pada kakao bubuk dari biji kakao (tanpa fermentasi - tanpa sangrai). Hal ini disebabkan karena selama fermentasi terjadi proteolitis, dimana kadar protein dalam kotiledon biji kakao akan terurai menjadi asam-asam amino dengan adanya enzim protease sehingga terjadi kenaikan kandungan nitrogen terlarut dalam biji dan sebagian dari hasil degradasi protein hilang karena terdifusi melalui kulit biji. Meningkatnya kadar nitrogen terlarut selama fermentasi menyebabkan meningkatnya kandungan asam amino bebas. Menurut Haryadi dan Supriyanto (2012), selama fermentasi terjadi peningkatan kadar total asam amino bebas sampai fermentasi 5 hari 
dan terjadi penurunan setelah hari ke enam. Selama proses penyangraian, biji kakao akan mengalami perubahan sifat fisika dan kimia, dimana senyawa pembawa citarasa dan aroma khas cokelat seperti pirazin, karbonil, ester dan sebagainya meningkat secara nyata selama proses penyangraian (Noor-Soffalina et al., 2009).
Asam Amino Esensial dan Non Esensial dari Biji Kakao dan Kakao bubuk

Hasil analisis asam amino esensial dan non esensial biji kakao tanpa fermentasi, biji kakao fermentasi, kakao bubuk dari biji kakao (tanpa fermentasi - tanpa sangrai), dan kakao bubuk dari biji kakao (fermentasi sangrai) dapat dilihat pada Gambar 2 dan 3.

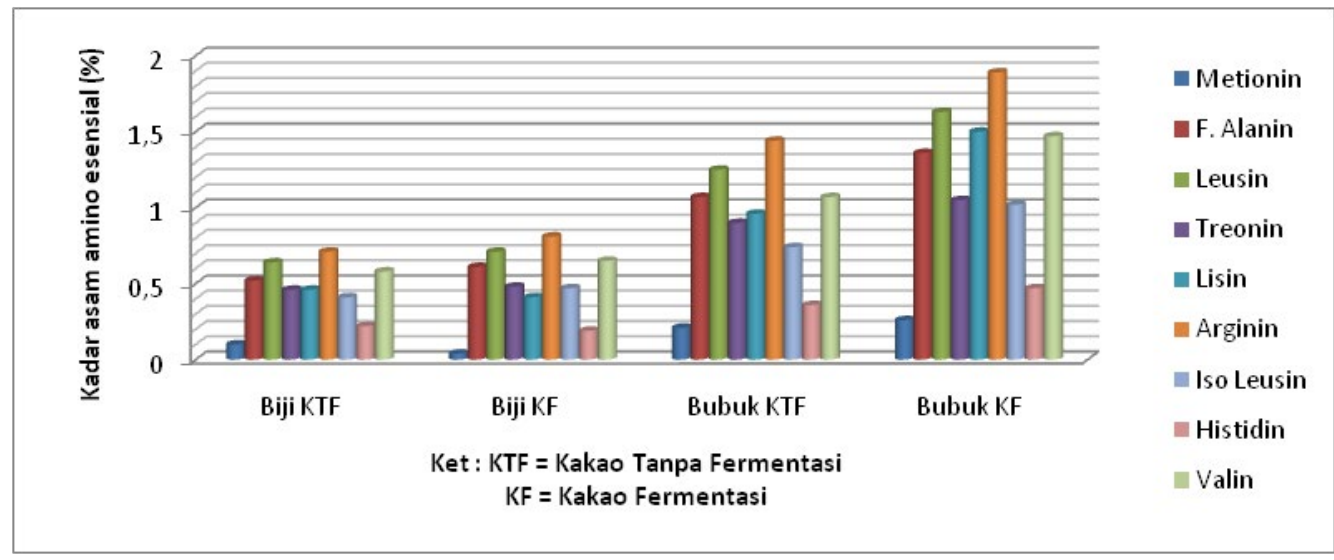

Gambar 2. Histogram asam amino esensial biji kakao tanpa fermentasi, biji kakao fermentasi, kakao bubuk dari biji kakao (tanpa fermentasi - tanpa sangrai), dan kakao bubuk dari biji kakao (fermentasi - sangrai).

Pada Gambar 2, terlihat bahwa pada umumnya kadar asam amino esensial biji kakao fermentasi lebih tinggi dari pada biji kakao tanpa fermentasi. Jenis asam amino esensial biji kakao yang terdeteksi pada penelitian ini antara lain: Metionin, fenilalanin, leusin, treonin, lisin, arginine, iso leusin, histidin, dan valin. Jenis asam amino esensial yang mengalami peningkatan setelah fermentasi yaitu fenil alanin, Leusin, treonin, arginin, iso leusin, dan valin. Menurut Zak dan Keeney (1976), bahwa biji kakao yang telah melalui proses fermentasi akan mengalami peningkatan kadar asam amino bebas khususnya leusin, fenil- alanin, alanin, valin, dan asam glutamate. Menurut Adeyeye, et al.,(2010), perlakuan proses fermentasi dapat meningkatkan kadar asam amino nib kakao khususnya Lisin, histidin, arginin, serin, glutamin, glisin, alanin, valin, iso leusin, tirosin, dan fenil alanin. Hal ini berarti bahwa proses fermentasi dapat meningkatkan kadar asam amino, baik asam amino esensial maupun asam amino non esensial. Asam amino esensial adalah asam amino yang sangat penting bagi tubuh tetapi tubuh tidak bisa memproduksinya sehingga perlu dari asupan atau sumber dari luar tubuh. Asam amino esensial sering juga disebut asam amino indispensable. Manfaat asam amino terhadap kesehatan adalah : menghambat pertumbuhan tumor dan kanker, meningkatkan detoksifikasi amonia, merangsang produksi hormon pertumbuhan, memperkuat tulang serta kolagen, menjaga kesehatan jantung, membantu menghindari depresi, dan meningkatkan daya ingat (Anonim, 2013).

Dari Gambar 2, juga terlihat bahwa kakao bubuk baik yang diolah (dari biji kakao fermentasi - sangrai) maupun (dari biji kakao tanpa fermentasi - tanpa sangrai) mengalami peningkatan kadar asam amino esensial yang sangat tinggi dibanding kadar asam amino esensial yang terkandung dalam biji kakao itu sendiri. Hal ini disebabkan karena pada biji kakao mengandung kadar lemak kurang lebih $50 \%$, dan setelah dilakukan pengepressan, kandungan lemak pada kakao bubuk berkurang sehingga konsentrasi senyawa-senyawa fungsional (khususnya polifenol dan asam amino) dalam kakao 
bubuk meningkat. Dari Gambar 2, terlihat bahwa jenis asam amino esensial dari ke empat jenis produk yang kadarnya ratarata paling tinggi adalah arginine, kemudian leusin, valin, fenil alanine, treonin, isoleusin, lisin, histidin, dan yang paling rendah adalah metionin.

Menurut Mulyadi, (2015) fungsi asam amino arginine, atau L-arginin, adalah untuk aktivitas sistem kekebalan tubuh, penyembuhan luka, membantu meregenerasi hati yang rusak, diperlukan untuk produksi dan pelepasan hormon pertumbuhan, meningkatkan pelepasan insulin dan glucagon, membantu dalam penyembuhan melalui sintesis kolagen, mengurangi ukuran tumor, dan diperlukan untuk spermatogenesis. Sedangkan Leusin dalam menjalankan fungsinya bersinerji dengan isoleusin. Leusin berfungsi membangun dan memperbaiki otot, mengatur metabolisme gula dan lemak, meningtkan produksi hormon, dan membantu penyembuhan tulang. Valin berfungsi dalam sistem saraf dan pencernaan, membantu gangguan saraf otot, mental, emosional, insomnia, keadaan gugup, memacu koordinasi otot, membantu perbaikkan jaringan yang rusak, menjaga keseimbangan nitrogen dalam tubuh. Sedangkan Treonin bermanfaat untuk mencegah dan mengobati penyakit gangguan mental. Sebenarnya asam amino ini bekerja pada sistem pencernaan, dan melindungi hati. Defisiensi treonin pada anak-anak dapat berakibat gangguan mental berupa mudah tersinggung (Anonim, 2017).

$$
\text { Isoleusin diperlukan dalam }
$$

produksi dan penyimpanan protein oleh tubuh, pembentukan hemoglobin. Juga berperan dalam metabolisme dan fungsi kelenjar timus dan kelenjar pituitary diperlukan untuk pertumbuhan yang optimal, mempertahankan keseimbangan nitrogen dalam tubuh, diperlukan dalam pembentukkan asam amino non-esensial lainnya, penting untuk pembentukkan hemoglobin dan menstabilkan kadar gula dalam darah sedangkan lisin merupakan komponen penting dan tak terpisahkan dari protein. Manfaat karnitin diantaranya adalah mendorong pertumbuhan dan pengembangan tubuh dengan meningkatkan pembentukan kolagen, mendukung produksi protein lain seperti enzim, antibodi dan hormon, meningkatkan kesehatan tulang dengan meningkatkan penyerapan kalsium serta mencegah osteoporosis (Anonim, 2015). Fungsi utama Metionin: membantu dalam pemecahan lemak, prekursor dari asam amino sistein dan taurin, membantu mengurangi kadar kolesterol darah, membantu dalam menetralkan racun dalam hati, membantu mencegah gangguan dari rambut, kulit, kuku, aktivitas antioksidan, dan prekursor untuk karnitin (Mulyadi, 2015).

Dari Gambar 3, terlihat bahwa kandungan asam amino non esensial pada biji kakao fermentasi lebih tinggi dibanding biji kakao tanpa fermentasi, demikian pula kakao bubuk dari biji kakao (fermentasi sangrai) mempunyai kandungan asam amino non esensial lebih tinggi pada kakao bubuk dari biji kakao (tanpa fermentasi - tanpa sangrai). Jenis asam amino non esensial yang terdeteksi pada penelitian ini antara lain: asam aspartat, asam glutamat, serin, glisin, alanin, dan tirosin. Asam amino non esensial adalah asam amino yang penting bagi tubuh tetapi tubuh bisa membuatnya sendiri sehingga tidak perlu secara langsung dari asupan atau sumber dari luar. Asam amino non esensial disebut juga asam amino dispensable. Dari Gambar 3 juga terlihat bahwa jenis asam amino non esensial yang paling menonjol pada kakao bubuk baik dari biji kakao (fermentasi - sangrai) maupun dari biji kakao (tanpa fermentasi - tanpa sangrai) adalah asam glutamat dan asam aspartat, sedangkan jenis asam amino non esensial lainnya (serin, glisin, alanine, dan tirosin) mempunyai nilai yang hampir sama. Hal ini sesuai hasil penelitian Adeyeye et al., (2010), nib kakao fermentasi mempunyai kandungan asam glutamat dan aspartat yang lebih besar dari pada nib kakao tanpa fermentasi, dimana asam glutamat berada pada posisi pertama dan asam aspartat pada posisi ke dua.

Gambar 3. Histogram asam amino non 


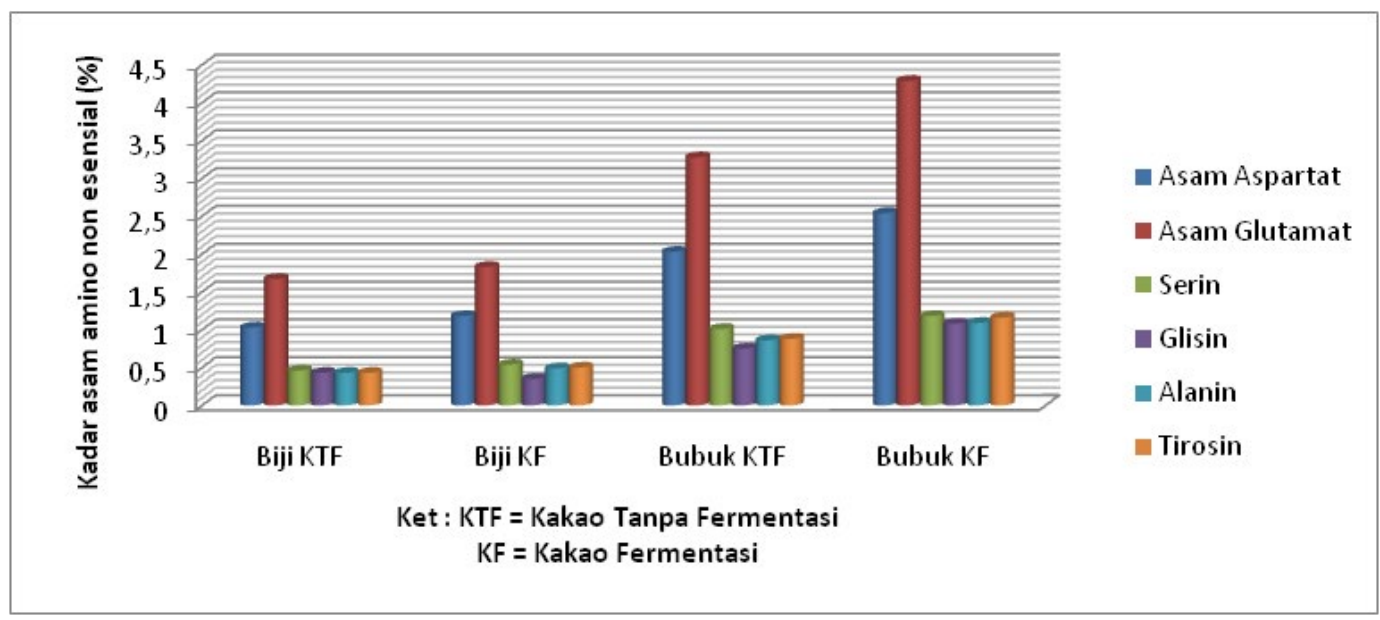

esensial biji kakao tanpa fermentasi, biji kakao fermentasi, kakao bubuk dari biji kakao (tanpa fermentasi - tanpa sangrai), dan kakao bubuk dari biji kakao (fermentasi - sangrai)

Asam glutamat memiliki peran penting dalam metabolisme gula dan lemak, membantu dalam transportasi kalium ke dalam cairan tulang belakang, membantu memperbaiki gangguan kepribadian. Asam glutamat digunakan sebagai bahan pengobatan dalam mengatasi penyakit epilepsy, retardasi mental, distrofi otot, dan bisul. Sedangkan Asam aspartat memiliki manfaat dalam membantu menjaga metabolisme, mengatasi kelelahan dan depresi. Selain itu mendorong molekul dinukleotida koenzim nikotinamida adenin (NADH) dari tubuh utama menuju mitokondria dalam sel, dimana asam aspartat digunakan untuk menghasilkan adenosine triphosphate (ATP), memberikan energi untuk kekuatan semua aktivitas seluler. Asam Aspartat membantu mentransportsikan mineral yang dibutuhkan untuk membentuk RNA dan DNA yang sehat dalam sel, memperkuat sistem kekebalan tubuh dengan membantu meningkatkan produksi imunoglobulin dan antibodi. Asam aspartat dapat mempertajam otak dengan cara meningkat konsentrasi NADH di otak, yang diduga untuk meningkatkan produksi neurotransmitter dan bahan kimia yang diperlukan untuk fungsi mental normal (Anonim, 2017).

\section{SIMPULAN}

Dari hasil dan pembahasan dapat disimpulkan bahwa kandungan senyawa fungsional polifenol lebih tinggi pada biji kakao tanpa fermentasi dibanding biji kakao fermentasi, sebaliknya kandungan senyawa fungsional asam amino lebih rendah pada biji kakao tanpa fermentasi dibanding biji kakao fermentasi. Demikian pula senyawa fungsional polifenol lebih tinggi pada kakao bubuk yang diolah dari (biji kakao tanpa fermentasi - tanpa sangrai) dibanding yang diolah dari (biji kakao fermentasi - sangrai), sebaliknya kandungan senyawa fungsional asam amino lebih rendah pada kakao bubuk yang diolah dari (biji kakao tanpa fermentasi - tanpa sangrai) dibanding kakao bubuk yang diolah dari (biji fermentasi - sangrai).

\section{DAFTAR PUSTAKA}

Ackar, D., K.V. Landic, M. Valek, D. Subaric, B. Milicevic, J. Babic and $\mathrm{H}$. Nedic. 2013. Cocoa polyphenols: can we consider cocoa and chocolate as potential functional food. Journal of Chemistry 13: 289-296.

Adeyeye, E.I., Akinyeye, R.o., Ogunlade, I., Olaofe, O., Boluwade, J.O 2010. Effect of farm and industrial bprocessing on the amino acid of cocoa beans. Food Chemical, $118: 357-363$. 
Afoakwa, E.O. 2008. Cocoa and chocolate consumption: Are there aphrodisiac and other benefits for human health? South African Journal of Clinical Nutrition 21 (3): 107-113.

Afoakwa, E.O., J. Quao., F.S. Takrama., A.S. Budu and F.K. Saalia. 2012. Changes in total polyphenols, o-diphenols and anthocyanin concentration during fermentation of pulp pre-conditional $\begin{array}{llll}\text { cocoa (Theobroma cocoa L.). } & \text { L }\end{array}$ International Food Research Journal 19 (3): 1071-1077.

Afoakwa, E.O., J.E. Kongor., J.F. Takrama., A.S. Budu and H. Mensah-Brown. 2013. Effects of pulp preconditioning on total polyphenols, O-diphenols and anthocyanin concentrations during fermentation and drying of cocoa (Theobroma cocoa L.) beans. Journal of Food Science and Engineering 3 (20): 235-245.

Albertini, B., A. Schobbrn, Guanaccia, F. Inrlli, M.D. Vechia, M. Ricci, G.C. Di Renzo, dan P. Blasi. 2015. Effect of Fermentation and Drying on Cocoa Polyphenols. J. Agric. Food Chem. 63(45): p 9948- 9953.

Anonim, 2013. Apa Manfaat Asam Amino? Makanan Yang Mengandung Asam Amino. http://amazine.co/18021/apamanfaat-asam amino-mkanan-yangmengandung-asam-amino/

Anonim, 2015. www.referensisehat.com , Asam Amino > Nutrisi. Diakses tgl 24 Agt 2015.

Anonim, 2017. AsamAmino Esensial dan Non Esensial $\quad$ https://www.artikelbelajar. com/asam-amino-esensial-dan-nonesensial-pengertian-jenis. Diakses tgl 31 Maret 2017.

Cooper, K.A., E. Campos-Gimenez, D.J. Alvarez, K. Nagy, J.L. Donovan and G. Williamson. 2007. Rapid reversed phase ultra-performance liquid chromatography analysis of the major cocoa polyphenols and interrelationships of their concentrations in chocolate. Journal of Agricultural and Food Chemistry 55: 2841-2847.
Crozier, S.J., A.G. Preston, J.W. Hurst, M.J. Payne, J. Mann, L. Hainly and D.L. Miller. 2011. Cocoa seeds are a "Super Fruit": A comparative analysis of various fruit powders and products. Chemistry Central Journal 5: 1-6.

Cruz, J.F.M., Leite, P.B., Soares, S.E. dan Bispo, E.S. (2013). Assessment of the fermentative process from different cocoa cultivars produced in Southern Bahia, Brazil. African Journal of Biotechnology 12(33): 5218-5225.

De-Brito, E.S., N.H.P. Garcia., M.I. Gallao., A.L. Cortelazzo., P.S. Fevereiro and M.R. Braga, 2000. Structural and chemical changes in cocoa (Theobroma cocoa L) during fermentation, drying and roasting. Journal of Science of Food and Agriculture 81: 281-288.

Di-Mattia, C., M. Martuscelli, G. Sacchetti, I. Scheirlinck, B. Beheydt, D. Mastrocola and P. Pittia. 2013. Effect of fermentation and drying on procyanidins, antiradical activity and reducing properties of cocoa beans. Food Bioprocess Technology 6: 34203432. Haryadi dan Supriyanto. (2012). Teknologi Cokelat. Gadjah Mada University Press, Yogyakarta.

ICCO. 2012. International Cocoa Organization Quarterly Bulletin of Cocoa Statistics,

Vol. XXXVIII, No. 4, Cocoa year 2011/2012. http://www.icco.org/ (7 Januari 2013).

Janeiro, P. and A.M.O. Brett. 2004. Catechin electrochemical oxidation mechanism. Analytica Chimica Acta 518: 109-115.

Kelishadi, R.M.D. 2005. Cocoa to cocoa to chocolate: healthy food? ARYA Journal 1: 28-34.

Kusuma, Y.T.C., S, Suwasono.S, Yuwanti. 2013. Pemanfaatan biji kakao inferior campuran sebagai sumber antioksidan dan antibakteri. Berkala IImiah Pertanian 1(2): 33-37.

Latif, R. 2013. Chocolate/cocoa and human health: a review. The Journal of Medicine 71(2): 63-68.

Mattia, CD., M. Martusselli, G. Sachchetti, I. Schrirlinck, B. Behheydt, D. Mastrocola, dan P. Pittla. 2013. Effect of Fermentation and Drying on 
Procyanidins, Antiradical Activity and Reducing Properties. Food Bioprocess Technol. 6: 3420-3432.

Meursing, E.H. (1983). Cocoa Powder for Industrial Processing 3 Edition. Cacao fabriek DeZaan B.V.

Minifie, B.W. (1982). Chocolate, Cocoa and Confectionery. AVI Publ. Co. Inc., Wesport, Conecticut.

Misnawi. 2003. Influences of Cocoa Polyphenols and Enzyme Reaction on The Flavor Development of Unfermented and Under-Fermented Cocoa Beans. Thesis of Doctor of Philosophy Universiti Putra, Malaysia. $329 p$.

Misnawi and S. Jinap. 2003. Effect of cocoa bean polyphenols on sensory properties and their changes during fermentation. Pelita Perkebunan 19 (2): 90-103.

Misnawi, B. Jamilah and S. Nazamid. 2004. Effect of polyphenol concentration on pyrazine formation during coco liquor roasting. Food Chemistry 85 (1): 7380.

Mulato, S. ,Widyotomo., Misnawi dan E. Suharyanto. 2005. Pengolahan Primer dan Sekunder. Jember: Pusat Penelitian Kopi dan Kakao Indonesia.

Mulyadi, T. 2015. Dua Puluh Macam Asam Amino dan Fungsinya. budisma. net/2015/10/20-macam-asam-aminodan-fungsinya.html. Diakses tgl 20 oktober 2015.

Nazaruddin, R., Seng L, Hassan, O., dan Said $M, 2006$. Effect of pulp pre-conditioning on the content of polyphenols in cocoa beans (Theobroma cacao) during fermentation industrial crops and products, 24: $87-94$.

Nestle Research Centers. 2010. Focos on: Polyphenols in chocolate. Nestle Research Centers. 3p.
Noor-Soffalina, S.S., S. Jinap, S. Nazamid and S.H.A. Nazimah. 2009. Effect of polyphenol and $\mathrm{pH}$ on cocoa Mailard related flavour procursors in a lipidic model system. International Journal of Food Science and Technology 44: 168180.

Othman, A., A. Ismail, N.A. Ghani and I. Adenan. 2007. Antioxidant capacity and phenolic content of cocoa beans. Food Chemistry 100: 1523-1530.

Othman, A., A.M.M. Jalil, K.K. Wang, A. Ismail, N.A. Ghani and I. Adenan. 2010. Epicatechin content and antioxidant capacity of cocoa beans from four different countries. African Journal of Biotechnology 9 (7): 10521059.

Redovnikovic, I.R., K. Delonga, S. Mazor, V. Dragovic-Uzelac, M. Caric and J. Vorkapic-Furac. 2009. Polyphenolic content and composition and antioxidative activity of different cocoa liquors. Czech Journal of Food Sciences 27 (5): 330-337.

Watson, R.R., V.R. Preedy and S. Zibadi. 2012. Chocolate in Health and Nutrition. Humana Press brand of Springer, New York Heidelberg Dordrecht London. $541 \mathrm{p}$.

Wollgast, J and E. Anklam, 2000. "Polyphenols in chocolate: is there a contribution to human health?" Food Research International, vol. 33, no. 6, pp. 449-459, 2000.

Yunus, M.R., A. Assa, dan R. Pasae. 2013. Pengembangan Pohon Industri Kakao dengan Metode Conceptual Entity Relationship, J. Industri Hasil Perkebunan, 8(1).

Zak, D.L and G. Keeney, (1976). Implication of bacillus subtilis in the sythesis of tetramethyl phyrazine during fermentation of cocoa beans. J. Sci. Food Agric. 10 (12). 